Zabytkoznawstwo i Konserwatorstwo XLIV, Toruń 2013

Tomasz Kozielec*, Grażyna Szczepańska**, Grzegorz Trykowski**

* Zakładu Konserwacji Papieru i Skóry WSP UMK

** Pracowni Analiz Instrumentalnych Wydziału Chemii UMK

\title{
Przykłady wykorzystania analizy SEM-EDX do badań zabytkowych skór garbowanych związkami metali
}

\section{Skóry garbowane związkami mineralnymi \\ - zarys tematyki}

Q kóra jest jednym z najstarszych materiałów, który człowiek nauczył $\bigcirc$ się przetwarzać i wykorzystywać dla celów użytkowych: na elementy narzędzi rolniczych, odzienie, oprawy rękopisów, siodła, kołczany, rękawiczki, torby etc. Jest ona wytworem zwierzęcym o niezwykłej strukturze. Ma budowę warstwowa, składa się głównie z sieci włókien kolagenowych, a struktura ta jest różna w poszczególnych warstwach skóry. Składa się z naskórka, błony licowej, warstwy termostatycznej, warstwy siatkowej oraz tkanki podskórnej. Dwie zewnętrzne warstwy są usuwane w procesie wyprawy, dlatego budowa skóry surowej różni się od budowy skóry wyprawionej (rys. 1). Różnice te zarysowują się także w składzie chemicznym - podczas wyprawy usuwana jest większa ilość substancji niekolagenowych znajdujących się w tkance skóry. W historii znanych było bardzo wiele metod wyprawiania skór, w tym ich garbowania. Wyprawa jest to szereg procesów technologicznych, które mają za cel przemienić bardzo nietrwała skórę surową (tj. szybko psującą się i nieodporną na wodę, wilgoć) w wyrób zdatny do użycia, który ma mieć już dużo większą odporność na 
wspomniane czynniki niszczące. Wyprawa obejmuje trzy duże bloki technologiczne (składające się z mniejszych procesów jednostkowych). Są to: 1) tzw. warsztat mokry, w którym skóry są poddawane oczyszczaniu, mechanicznej i chemicznej obróbce, 2) garbowanie skór, czyli wprowadzenie w tkankę skórną związków ją garbujących; 3) wykańczanie skóry (m.in. natłuszczanie, suszenie, barwienie, obróbka mechaniczna, nanoszenie powłok tworzących skórę bardziej odporną na wnikanie wody, w celu nadania połysku, czy też nadawanie faktury).

Do grupy substancji garbujących używanych dawniej, jak również współcześnie należą m.in. związki metali. W grupie skór znajdujących się w zabytkowych kolekcjach lub będących elementami obiektów można spotkać najczęściej skóry garbowane przy użyciu soli glinowych - tzw. „garbowanie glinowe" / ,ałunowe zwykłe". Skóry takie garbowano przy użyciu roztworu ałunu ${ }^{2}$ glinowo-potasowego $\mathrm{Al}\left(\mathrm{SO}_{4}\right)_{3} \cdot \mathrm{K}_{2} \mathrm{SO}_{4} \cdot 12 \mathrm{H}_{2} \mathrm{O}$ z dodatkiem powszechnie używanej soli, jaka jest chlorek sodu, a od kiedy przemysł w XIX wieku zaczął wytwarzać masowo siarczan glinu $\mathrm{Al}\left(\mathrm{SO}_{4}\right)_{3} \cdot 18 \mathrm{H}_{2} \mathrm{O}$, sól ta zaczęła być również używana w procesie garbowania glinowego.

Użycie soli glinu oraz garbników roślinnych zalicza się do jednych z najstarszych substancji garbujących ${ }^{3}$. Stosowane od czasów starożytnych ałuny używane były powszechnie w medycynie, farbiarstwie, garbowaniu skór i do innych jeszcze celów. Były powszechnie znane w świecie starożytnym, m.in. w Mezopotamii, Egipcie, Grecji, Rzymie. Najstarszym znanym surowcem, z którego uzyskiwano ałuny, był ałunit i kamień ałunowy (ang. alum stone). Wytwarzano je w dużych ilościach w związku ze sporym zapotrzebowaniem. W Europie do masowego wytwarzania ałunu doszło w XIII wieku. Jego produkcja była rozwijana przez wieki, a zaczęła się zmniejszać

1 H. R. Procter, The Making of Leather, Cambridge 1914, s. $80 \mathrm{i} \mathrm{n.}$

2 Ałuny to siarczany podwójne o wzorze: $\mathrm{M}^{\mathrm{I}} \mathrm{M}^{\mathrm{III}}\left(\mathrm{SO}_{4}\right)_{2} \cdot 12 \mathrm{H}_{2} \mathrm{O} \cdot \mathrm{M}^{\mathrm{I}}$ oznacza kation metali jednowartościowych: $\mathrm{K}, \mathrm{Na}, \mathrm{Rb}, \mathrm{Tl}$, Cs lub kation amonowy, natomiast $\mathrm{M}^{\mathrm{III}}$ oznacza metale trójwartościowe: Al, Fe, Cr, In, Ga, Co, V, Mn, Sc.

3 M. Levey, Alum in Ancient Mesopotamian Technology, "Isis" 1958, t. 49, nr 2, s. 168; M. Levey, M. Krek, H. Haddad, Some Notes on the Chemical Technology in an Eleventh Century Arabic Work on Bookbinding, "Isis" 1956, t. 47, nr 3, s. 240. 
wraz z pojawieniem się masowej produkcji siarczanu glinu ${ }^{4}$. Siarczan glinu zaczął przemysłowo wytwarzać niejaki Pommier z Paryża w 1845 roku 5 . Używano go w przemyśle m.in. garbarskim i papierniczym. Na przestrzeni wieków opracowano wiele różnych metod garbowania skór z użyciem soli glinu. Jednym z nich jest tzw. wyprawa glacé, polegająca na traktowaniu surowca skórzanego papką składającą się z roztworu ałunu glinowo-potasowego i soli kuchennej z dodatkiem środka natłuszczającego (np. żółtka jaj kurzych) i napełniającego (np. mąka pszenna) ${ }^{6}$. Proces wyprawy skóry solami glinu z różnymi dodatkowymi substancjami można było przeprowadzić etapowo - najpierw poprzez zastosowanie garbowania glinowego, a następnie wprowadzenie do skóry papki. Wykorzystywano papki o różnym składzie. Wiele różnorodnych wariantów wyprawy skór przy użyciu garbników glinowych z zastosowaniem dodatków, a także sposoby barwienia białych skór opisał m.in. Alexander Watt'. W Zakładzie Konserwacji Papieru i Skóry UMK w Toruniu, w ramach zajęć z technologii skóry prowadzonych dla przyszłych konserwatorów, odtwarzane są niektóre z tych dawnych metod, co cieszy się dużym zainteresowaniem.

Nowo wytworzone skóry garbowane solami glinu sa jasnobiałe lub białokremowe, natomiast te, które występują w obiektach zabytkowych, mogą zachować czasem swoją charakterystyczną jasną barwę, często jednak mają barwę kremowa, kremowo-żółtą lub żółtą, co jest efektem zmian zachodzacych podczas procesów starzeniowych. Nierzadko skóry te są także znacznie zabrudzone i dopiero w wyniku prac konserwatorskich, dzięki mechanicznemu i chemicznemu usunięciu zanieczyszczeń z ich powierzchni, odzyskują część swojego dawnego blasku. Skóry białe garbowane glinowo, z uwagi na ich stosunkowo duża jasność i dobra trwałość, stosowane są w pracach konserwatorskich do uzupełnień - rekonstrukcji ${ }^{8}$. Zwraca

${ }^{4}$ L. Geschwind, The Manufacture of Alum and the Sulphates and Other Salts of Alumina and Iron, London 1901, s. 163-164.

5 Ibidem, s. 134.

6 Ch. T. Davies, The Manufacture of Leather, Philadelphia-London 1885, s. 653-654.

7 A. Watt, Leather Manufacture, New York-London 1906, s. 306-322.

8 P. N. Banks, The Treatment of an 1855 British Paper Specimen Book, "Bulletin of the American Group. International Institute for Conservation of Historic and Artistic Works" 1972, t. 12, nr 2, s. 92. 
się jednak uwagę na ich wady m.in. niższą temperaturę skurczu względem skór garbowanych roślinnie. Skóra garbowana glinowo jako materiał zabytkowy poddawany konserwacji i używany do konserwacji była przedmiotem badań konserwatorki Marie Vest?.

W historii skóry białe garbowane z użyciem związków glinu wykorzystywano (w zależności od zastosowanego wariantu wyprawy) do różnych celów ekskluzywnych, np. jako materiały introligatorskie (np. do oklejenia okładzin, fot. 1, 2), galanteria (np. rękawiczki, cylindry, kapelusze, portmonetki, paski), buciki, kamizelki, kaftany (fot. 3, 4), reprezentacyjne rzędy końskie, elementy siodeł. Pojawienie się kolei, samochodów oraz innych środków transportu stworzyło możliwość zastosowania białych skór także i w pojazdach do celów ozdobnych, np. do wykonywania tapicerek. Garbowanie ałunowe zwykłe (ałun i chlorek sodu) stosowano także do wyprawy skór futerkowych ${ }^{10}$. W technologii garbarskiej używano również rozmaitych kombinacji garbowania, np. garbowanie glinowo-roślinne czy też glinowo-chromowe.

Innym rodzajem garbowania mineralnego, na które zwrócono uwagę w niniejszym artykule, jest garbowanie zwiazkami zasadowymi chromu(III), np. $\mathrm{Cr}_{2}(\mathrm{OH})_{2}\left(\mathrm{SO}_{4}\right)_{2} \cdot \mathrm{Na}_{2} \mathrm{SO}_{4}, \mathrm{Cr}_{4}(\mathrm{OH})_{6} \cdot\left(\mathrm{SO}_{4}\right)_{3}{ }^{11}$. Jest to metoda stosunkowo nowa, ponieważ weszła w użycie w II połowie XIX wieku ${ }^{12}$. Technologia garbowania chromowego jest obecnie dominującym sposobem garbowania na świecie, m.in. ze względu na jej niskie koszty, szybkie wnikanie garbnika w całą grubość tkanki skórnej oraz inne, specyficzne cechy wyrobu (m.in. wysoką temperaturę skurczu włókien kolagenowych $>100^{\circ} \mathrm{C}$ ). Skóry garbowane chromowo używane są m.in. w introligatorstwie, bywały także wykorzystywane przez niektórych konserwatorów w pracach restauratorskich do uzupełnień ubytków w zabytkowych obiektach skórzanych, dlatego też towarzyszą cennym obiektom zabytkowym. Stawiano je wysoko wśród innych skór m.in. ze względu na dużą elastyczność.

9 M. Vest, White tawed leather - aspects of conservation, Preprint from the $19^{\text {th }}$ International Congress of IADA, Copenhagen, August 15-21, 1999, s. 67-72.

10 J. W. Stevens, Leather Manufacture, London 1891, s. 235.

11 W. Lasek, Kolagen. Chemia i mykoraystanie, Warszawa 1978, s. 303.

12 A. Watt, op. cit., s. 323 i n. 
W technologii garbarskiej stosowano jeszcze inne rodzaje garbowania mineralnego, np. związkami żelaza ${ }^{13}$, cyrkonu, tytanu ${ }^{14}$. Specyficznym rodzajem garbowania było garbowanie siarkowe, polegające potraktowaniu skóry roztworem tiosiarczanu sodu, a następnie kwasem siarkowym, w wyniku czego na włóknach kolagenowych osiadała siarka koloidalna. Istnienie tych metod jedynie zasygnalizowano, nie będa bowiem omawiane w artykule.

Innym rodzajem skóry wyprawionej jest pergamin, który jest skóra niegarbowana, poddaną specyficznej obróbce. W przeciwieństwie do skór przeznaczonych do garbowania, w tym przypadku używany podczas wyprawy wodorotlenek wapnia (etap wapnienia) nie jest usuwany ze skóry i w niej pozostaje. Ponadto w końcowych fazach obróbki pergaminu czasem praktykuje się wcieranie $\mathrm{w}$ jego powierzchnię węglanu wapnia w postaci kredy. Zarówno wodorotlenek, jak i węglan nie mają właściwości garbujących. Pergamin jest więc skóra niegarbowana, ale zawierająca w swojej strukturze związek mineralny w postaci $\mathrm{CaCO}_{3}$. Jednakże czasem pergaminy poddawano powierzchniowemu zagarbowaniu. Przykładem sa karty wykorzystywane jako podłoże do malowania miniatur książkowych, które pokrywano powierzchniowo roztworem ałunu glinowo-potasowego. Taki pergamin stawał się bardziej odporny na wodę będącą rozpuszczalnikiem farb miniatorskich i zapraw pod złocenia.

\section{Wykorzystanie}

\section{skaningowego mikroskopu elektronowego}

\section{z detektorem EDX}

\section{w badaniach próbek skór zabytkowych}

Spektrometr EDX (ang. energy dispersive X-ray), mierzaccy charakterystyczne promieniowanie rentgenowskiego emitowane przez próbkę pod wpływem

13 Skóry garbowane solami żelaza nie wytrzymały konkurencji z innymi metodami garbowania ze względu na niepożądane ich właściwości, J. Szczepański, Poglady na tworzenie sie skóry myprawionej, „Chemik Polski” 1904, R. 4, nr 30, s. 587.

${ }_{14} \mathrm{Sa}$ to nowe technologie garbowania. M. Kite, R. Thomson, Conservation of Leather and Related Materials, Amsterdam [etc.] 2006, s. 27-30. 
strumienia elektronów, służy do stosunkowo szybkiej identyfikacji pierwiastków w badanych materiałach. Począwszy od 1968 roku, kiedy to amerykańska firma „Gamma-Tech” zainstalowała pierwszy półprzewodnikowy detektor do mikroskopu skaningowego, nastąpił znaczny rozwój i rozpowszechnienie tej techniki. Mikroanaliza rentgenowska jest cennym narzędziem badawczym dla specjalistów z różnych dziedzin, w tym konserwatorów, ponieważ pozwala na wykrycie pierwiastków poniżej $0,1 \%$ wag., przy precyzji $1-5 \%$ analizowanego stężenia ${ }^{15}$. Konserwatorzy nie moga pozwolić sobie na pobranie dużych próbek z obiektów zabytkowych, dlatego też pobierane są najczęściej próbki w skali mikro. Przy zastosowaniu detektora EDX wykrywane są wszystkie pierwiastki, które mają liczbę atomową większą niż bor (B ma liczbę atomową $Z=5$ ). Jednakże należy podkreślić, że określenie zawartości pierwiastków lekkich obarczone jest dużo większym błędem niż pierwiastków ciężkich. Zanim próbka zostanie poddana badaniom przy wykorzystaniu detektora EDX, w celu uzyskania informacji o rozmieszczeniu pierwiastków w próbce wykorzystywany jest detektor umożliwiający wykrycie elektronów elastycznie odbitych BSE (ang. backscattered electrons). Analizy SEM-EDX i SEM-BSE są bardzo pomocne i chętnie wykorzystywane podczas badaniach różnego rodzaju obiektów zabytkowych, w tym obiektów skórzanych ${ }^{16}$. Detektor BSE uwidacznia kontrast związany ze składem pierwiastkowym badanej próbki (tzw. $Z$ kontrast). Jest to możliwe ze względu na zdolność odbijania elektronów przez atomy pierwiastków, która to zdolność w dużym stopniu zależy od liczby atomowej $\mathrm{Z}$ i rośnie wraz z jej wzrostem ${ }^{17}$. W praktyce oznacza to, że im większa średnia liczba atomowa, tym bardziej jasne sa miejsca (aż do bieli włącznie) na badanym obszarze próbki. Natomiast im mniejsza średnia liczba atomowa pierwiastków, tym ciemniejsze sa obszary (aż do szaro-

15 Mikeroskopia elektronowa, red. A. Barbacki, Poznań 2007, s. 16-17.

16 A. Le Gac, Preliminary research on glues made of tawed leather, parchment and rabbit-skin, [w:] Parchment and leather heritage. Conservation-Restoration, red. E. Jabłońska, T. Kozielec, Toruń 2012, s. 41 i n.; G. Abdel-Maksoud, Analytical techniques used for the evaluation of a $19^{\text {th }}$ century quranic manuscript conditions, "Measurement" 2011, t. 44, nr 9, s. 1612; B. Pemberton, P. Nell, Identification of a white substance on $20^{\text {th }}$ century leather bindings, "AICCM Bulletin", 2008, t. 31, s. $28-35$.

17 Mikeroskopia elektronowa, s. 85. 
czarnego, czarnego), które tworzą te pierwiastki w obrębie próbki (fot. 5, 8). Na podstawie obrazu mikroskopowego uzyskanego przy użyciu detektora BSE możemy zorientować się w rozmieszczeniu pierwiastków cięższych i lżejszych w obrębie próbki i wybrać miejsca do badań szczegółowych przy użyciu detektora EDX.

Analiza SEM-EDX stwarza duże możliwości w analizowaniu składu pierwiastkowego próbek. Jak przykłady można wymienić:

a) uzyskanie tzw. map rozmieszczenia pojedynczych pierwiastków (ang. mapping) (fot. 6, 7);

b) uzyskanie map dla dwóch lub więcej pierwiastków jednocześnie (fot. 9, 10);

c) nałożenie map pierwiastków na obraz uzyskany przy użyciu detektora BSE (a więc obrazu kolorowego na obraz w skali odcieni szarości);

d) wykonanie analizy całej powierzchni badanej próbki lub jej fragmentu poprzez: zaznaczenie obszarów o różnych kształtach (fot. 11), zaznaczenie punktów lub linii (jednocześnie można zaznaczyć wiele wybranych obszarów);

e) wykonanie analizy jakościowej i ilościowej pierwiastków w obrębie badanego obszaru. Między innymi uzyskuje się wyrażoną w procencie atomowym informację o zawartości zidentyfikowanych pierwiastków (tab. 1). Dane te umożliwiają określenie przybliżonych wzorów sumarycznych substancji chemicznych znajdujących się w próbce. Ustalenie wzoru związku chemicznego ułatwia także porównanie miejsc nakładania się poszczególnych pierwiastków w mapach.

Ze względu na zróżnicowanie topograficzne próbki, badaniom poddawane są najczęściej następujące jej obszary:

a) powierzchnia próbki skóry;

b) przekrój próbki skóry (klasyczny: o kącie równym lub zbliżonym do $90^{\circ}$ ) - na całej jej grubości (próbka wycinana jest skalpelem chirurgicznym i obserwowana w postaci niezatopionej lub zatopionej w żywicy, np. akrylowej - „Duracryl Plus”);

c) powierzchnia próbki skóry wraz przekrojem skośnym - na całej grubości skóry (cięcie skośne wykonywane jest skalpelem chirurgicznym od warstwy licowej do strony mizdrowej, rys. 2);

d) fragmenty warstw skóry (np. z kruszącego się lica); 
Tabela. 1. Wyniki badań EDX próbki skóry garbowanej chromowo pochodzącej z łatki (po XX-wiecznych reperacjach) użytej do wtórnej oprawy (XVII w.) dla „Złotego Kodeksu" (Archiwum Archidiecezjalne w Gnieźnie). Procent atomowy wykrytych pierwiastków w 4 zaznaczonych miejscach próbki. Czcionką pogrubioną zaznaczono wyniki zawartości chromu (1,24\% atomowego) na przekroju skośnym (miejsce 7882), zawartości żelaza $(2,51 \%$ atomowego) na powierzchni (miejsce 7883$)$ oraz żelaza (6,38\% atomowego) na powierzchni (miejsce 7886 występowania od czerwieni żelazowej)

\begin{tabular}{|l|c|c|c|c|c|c|c|c|c|c|c|c|}
\hline $\begin{array}{c}\text { Miejsce / } \\
\text { /pierwiastki }\end{array}$ & $\mathrm{C}$ & $\mathbf{0}$ & $\mathrm{Na}$ & $\mathrm{Mg}$ & $\mathrm{Al}$ & $\mathrm{Si}$ & $\mathrm{S}$ & $\mathrm{Ca}$ & $\mathrm{Cr}$ & $\mathrm{Fe}$ & $\mathrm{Cu}$ & $\mathrm{Sn}$ \\
\hline 7882 & 35,25 & 61,22 & 0,55 & - & 0,42 & - & 0,90 & - & 1,24 & 0,43 & - & - \\
\hline 7883 & 29,75 & 65,69 & 0,61 & - & 0,44 & - & 0,40 & 0,19 & 0,18 & 2,51 & 0,23 & - \\
\hline 7884 & 16,96 & 74,86 & 0,98 & 0,56 & 0,61 & 0,35 & 0,57 & 0,31 & 0,16 & 1,28 & 0,44 & 2,92 \\
\hline 7886 & 33,64 & 56,76 & 1,09 & - & 0,68 & 0,42 & 0,66 & - & 0,38 & 6,38 & - & - \\
\hline
\end{tabular}

Na podstawie badań skór garbowanych m.in. mineralnie i skór pochodzących z różnych okresów stwierdzono następująca przydatność analizy SEM-EDX w badaniach konserwatorskich:

a) identyfikacja rodzaju garbowania skóry - umożliwia przybliżone określenie wieku powstania obiektu ze względu na stosowane garbniki mineralne oraz ukierunkowuje sposób postępowania konserwatorskiego (m.in. jakich środków i metod konserwatorskich można użyć);

b) analiza innych składników pierwotnych skóry (np. obecność mniejszej lub większej ilości wapnia pozostałego po procesie wapnienia skóry);

c) analiza składników wtórnych skóry w postaci zanieczyszczeń (w strukturze, na powierzchni);

d) analiza składników wtórnych skóry $\mathrm{w}$ postaci naniesionych warstw ozdobnych powstałych w wyniku: barwienia lub malowania skóry (fot. 9), pokrywania lica warstwami ochronnymi, wybłyszczającymi etc.;

e) analiza stopnia degradacji skóry, np. spowodowanej wpływem metali - głównie żelaza, miedzi, cynku (badanie stopnia migracji w głąb tkanki skórnej na przekrojach);

f) analiza wpływu środków konserwatorskich na skórę - zwłaszcza sposobu wnikania środków i głębokości ich penetracji (o ile w środku do konserwacji użyto pierwiastków możliwych do wykrycia w analizie);

g) wyodrębnienie skór w obiekcie zabytkowym użytych wtórnie od skóry oryginalnej, np. łatek w oprawie ze skór chromowych (fot. 9), 
podbarwionych na kolor brązowy i scalających się kolorystycznie z oryginalną oprawa; określenie rodzaju garbowania skór poddanych celowym, ale niewłaściwym zabiegom, np. przemalowanie białej oprawy (skóra garbowana glinowo) na kolor brązowy w celu zniwelowania rozległych zniszczeń mechanicznych czy zabrudzeń.

\section{Obecność w skórach wyprawionych pozostałości związków pomocniczych, środków używanych do zdobień oraz zanieczyszczeń}

Surowa skóra zwierząt zawiera składniki mineralne w ilościach około 0,5\%. Są to przede wszystkim: potas, wapń, magnez i żelazo, które występuja zazwyczaj w postaci chlorków, siarczanów, fosforanów i węglanów. W śladowych ilościach występują także: krzem, cynk, nikiel, arsen, fluor, i jod ${ }^{18}$. Związki te są częściowo usuwalne ze skóry w tzw. warsztacie mokrym, obejmującym m.in. zastosowanie środków chemicznych - odwapniania kwasami mineralnymi lub organicznymi czy biochemicznych - wytrawiania. Jednakże stopień usunięcia tych substancji zależy m.in. od jakości wyprawy.

W grupie skór garbowanych mineralnie poszukuje się pierwiastków tworzących związki chemiczne o właściwościach garbujących, są to więc głównie: $\mathrm{K}, \mathrm{Na}, \mathrm{S}, \mathrm{Al}, \mathrm{Cr}, \mathrm{Zr}$. Ważna jest także identyfikacja pierwiastków tworzących związki chemiczne używane w poszczególnych operacjach technologicznych, mających na celu przygotowanie tkanki skórnej do garbowania, jako środków pomocniczych stosowanych podczas procesu garbowania oraz wykańczania skór. W skórze zachodzą różne reakcje chemiczne pomiędzy wprowadzanymi środkami chemicznymi. Na przykład wprowadzany w strukturę tkanki skórnej roztwór ałunu lub siarczanu glinu podczas garbowania wchodzi $\mathrm{w}$ reakcję $\mathrm{z}$ resztkami wapnia pozostałymi po procesie wapnienia skóry ${ }^{19}$ W wyniku tej reakcji tworzy się gips. Obecność gipsu

18 W. Lasek, op. cit., s. 153.

19 Wodorotlenek wapnia szybko zamienia się w węglan pod wpływem $\mathrm{CO}_{2}$ z powietrza. Związki wapnia powstałe w skórze w procesie wapnienia (m.in mydła) powinny zostać ze 
w skórze może też być wynikiem użycia rozcieńczonego kwasu siarkowego w procesie odwapniania skóry (co czyniono od XIX wieku, pogarszając trwałość skóry) lub też być wynikiem reakcji między resztkami związku wapniowego z tlenkami siarki z powietrza. Jeszcze innym przykładem może być przereagowanie atramentu żelazowo-galusowego $z$ węglanem wapnia w skórze, np. na oprawach, po których pisano lub malowano atramentem żelazowo-galusowym. Na zachodzenie tej reakcji zwracał uwagę Robert Fuchs, omawiając wżery atramentowe na pergaminie ${ }^{20}$.

Obecność pozostałości związków chemicznych po niektórych operacjach technologicznych (mających miejsce zarówno przed garbowaniem, jak i nim) oraz zanieczyszczeń może skomplikować interpretację wyników badań, ponieważ poszerza skład pierwiastkowy badanych skór. Najczęściej identyfikowane pierwiastki, będące pozostałościami omawianych substancji pomocniczych, a także wchodzących w skład substancji używanych do zdobienia skór oraz osadzających się na skórze zanieczyszczeń przedstawiono w tabeli 2.

Tabela. 2. Przykłady substancji, z których moga pochodzić wskazane pierwiastki znajdujące się w skórach różnej wyprawy

\begin{tabular}{|c|c|}
\hline $\mathrm{Na}$ & $\begin{array}{l}\text { a) NaCl używany jako środek chroniący skóry surowe przed gniciem; używany jako dodatek w garbowaniu glinowym } \\
\text { b) sole chromowe stosowane do garbowania zawierające w składzie sód; } \\
\text { c) Na2S używany do przyspieszonego (tzw. zaostrzonego) wapnienia skór (Vide: Unhairing Hides by Sulphide of So- } \\
\text { dium, Cutler, Hall \& Borchers, Boston 1883); } \\
\text { d) pot ludzki (często na powierzchni skóry opraw ksiąg, rękawice) i zwierzęcy (siodła, uprzęże etc.) } \\
\text { e). woda stosowana podczas przeróbki skóry }\end{array}$ \\
\hline K & $\begin{array}{l}\text { a) pot ludzki } \\
\text { b) woda stosowana podczas wyprawy skóry }\end{array}$ \\
\hline $\mathrm{Cl}$ & $\begin{array}{l}\text { a) woda stosowana podczas wyprawy skóry } \\
\text { b) } \mathrm{CaCl} 2 \text { pozostały po odwapnianiu skóry roztworem } \mathrm{HCl}\end{array}$ \\
\hline $\mathrm{Al}$ & $\begin{array}{l}\text { a) Al(S04)3 · } 18 \text { H20 stosowany jako środek hamujący wzrost drobnoustrojów w klejach introligatorskich (klajstry); } \\
\text { b) Al(SO4)3 · } 18 \text { H2O używany jako środek pomocniczy w barwieniu skór (Vide: C. Morfit, The Arts of Tanning, Cur- } \\
\text { rying, and Leather Dressing, Philadelphia 1852, s. } 399 \text { i n.); } \\
\text { c) gleba (skóra z wykopalisk archeologicznych, zabrudzone uprzęże końskie i siodła, kołczany) } \\
\text { d) pył z ceglanych ścian (zniszczenia wojenne, remonty) }\end{array}$ \\
\hline
\end{tabular}

skóry usunięte w procesie tzw. odwapniania. Zawsze jednak zostaje pewna ich ilość, tym większa im niedokładniej przeprowadzony został proces odwapniania.

20 R. Fuchs, Wizery historycznych atramentów i retussy. Problemy ich restauracii, „Ochrona Zabytków" 1999, t. 52, s. 177. 


\begin{tabular}{|l|l|}
\hline P & $\begin{array}{l}\text { a) gleba } \\
\text { b) zanieczyszczenie pozostałe z surowców w siarczanie glinu lub ałunie glinowo-potasowym; }\end{array}$ \\
\hline $\mathrm{Mg}$ & $\begin{array}{l}\text { a) woda stosowana podczas wyprawiania skóry; } \\
\text { b) gleba }\end{array}$ \\
\hline $\mathrm{Si}$ & $\begin{array}{l}\text { a) gleba, ziarna piachu } \\
\text { b) zanieczyszczenie pozostałe z surowców w siarczanie glinu lub ałunie glinowo-potasowym; }\end{array}$ \\
\hline $\mathrm{Fe}$ & $\begin{array}{l}\text { a) woda stosowana podczas wyprawiania skóry; } \\
\text { b) czerwienie żelazowe (stosowane do barwienia / zdobienia skór); } \\
\text { c) zanieczyszczenie pozostałe z surowców w siarczanie glinu lub ałunie glinowo-potasowym; } \\
\text { d) gleba }\end{array}$ \\
\hline $\mathrm{Ca}$ & $\begin{array}{l}\text { a) sole wapnia (resztki pozostałe po odwapnianiu) } \\
\text { b) woda stosowana podczas wyprawiania skóry; } \\
\text { c) pył ze ścian (szlifowanie białych emulsji i zapraw podczas remontów); } \\
\text { d) laki barwne używane do barwienia skór (barwniki organiczne były często osadzane na węglanie wapnia); }\end{array}$ \\
\hline $\mathrm{Cr}$ & a) dwuchromian potasu używany jako środek pomocniczy przy barwieniu skór \\
\hline $\mathrm{S}$ & $\begin{array}{l}\text { a) pozostałości naskórka oraz resztek włosów w mieszkach (nieusunięte resztki podczas obróbki skóry - obecność ke- } \\
\text { ratyny zawierajajcej siarkę); } \\
\text { b) Na2S użyany do przyspieszonego (tzw. zaostrzonego) wapnienia skór } \\
\text { c) SOx z powietrza }\end{array}$ \\
\hline
\end{tabular}

Skóra, jak wiele innych materiałów zabytkowych, kumuluje przez wieki wiele zanieczyszczeń. Znaczna ilość pierwiastków wprowadzana jest także podczas garbowania skór ałunem glinowo-potasowym, ponieważ otrzymywano go m.in. z ałunitów. Ta grupa minerałów siarczanowych ma w swoim składzie różne pierwiastki, takie jak np.: Fe, P, Bi, Na, Ba, Ca ${ }^{21}$. Można stwierdzić, że skóry zabytkowe to swoista „tablica Mendelejewa”, gdyż znaczna część tworzących ja pierwiastków jest wykrywana w badanych próbkach. Zabrudzenia kurzem, błotem i wieloma innymi substancjami przyczyniają się do powstawania ciemnych nawarstwień na skórze (fot. 12, 13). Skład pierwiastkowy znacznie urozmaicają farby używane do dekoracji wyrobów skórzanych. Zidentyfikowanie w analizie SEM-EDX występujących w badanym materiale pierwiastków oraz ustalenie wzorów związków chemicznych pozwala określić wiek zabytku i/lub wykonanych zdobień i przemalowań. Szczególnie obficie zdobione są karty pergaminu - miniaturami, bordiurami i przepisywanymi tekstami. W wyniku odkształcenia się pergaminu, który jest materiałem bardzo wrażliwym na zmiany wilgotności powietrza, naniesione pigmenty osypują się i są identyfikowane w postaci pyłu

21 R. L. Frost, D. L. Wain, Near infrared spectroscopy of natural alunites, "Spectrochimica Acta” Part A: Molecular and Biomolecular Spectroscopy 2008, t. 71, nr 2, s. 490-495. 
na powierzchniach nieozdobionych. W zaprezentowanym w niniejszej pracy pergaminie zidentyfikowano pierwiastki tworzace mosiądz (stop miedzi i cynku). Mosiądz w postaci sproszkowanej użyto w celu wykonania imitacji złoceń w jednym z najbardziej cennych kodeksów, jakim jest „Złoty Kodeks" przechowywany w Archiwum Archidiecezjalnym w Gnieźnie (fot. 10).

\section{Uwagi końcowe}

Technika SEM-EDX jest bardzo przydatna podczas dokonywania charakterystyki skór, dzięki możliwości zidentyfikowania wielu pierwiastków znajdujących się $\mathrm{w}$ badanych próbkach, oraz określania rozmieszczenia tych pierwiastków w obrębie próbek. Interpretację wyników badań ułatwia znajomość podstaw technologii wyprawy skór i metod ich zdobień, jednocześnie należy zdawać sobie sprawę z obecności różnych rodzajów zanieczyszczeń wprowadzonych pierwotnie lub wtórnie do skór. Wyniki badań uzyskane z wykorzystaniem tej techniki nie daja jednak wszystkich informacji o badanych próbkach. W praktyce stosuje się także wiele innych analiz o charakterze uzupełniajacym, takich jak np. reakcje mikrochemiczne, obserwacje pod mikroskopem stereoskopowym, badania fluorescencji próbek wzbudzonej promieniami UV (najczęściej UV-a).

\section{Summary}

\section{Examples of application of the SEM-EDX technique to examination of antique mineral tanned leathers}

Application of the SEM-EDX technique for determination of elements in alum as well as chrome tanner leathers discussed in the article. These leathers are found in museum, library and archival collections. Alum tanner leathers are known since ancient period while chrome tanner leathers for 19th $\mathrm{c}$. Examples of the use of leather samples examination and range possibilities created by the technique presented. Additional substances (not being tannins) to be found in leather structure ad surface such as auxiliary agents, decorative layers, contaminations, focused on. The SEM-EDX technique is useful not only for characterization of elements composition of leathers, but also contributes to preservation of cultural heritage by giving possibilities of planning conservation treatments and examining influence of conservation chemicals on leathers. 


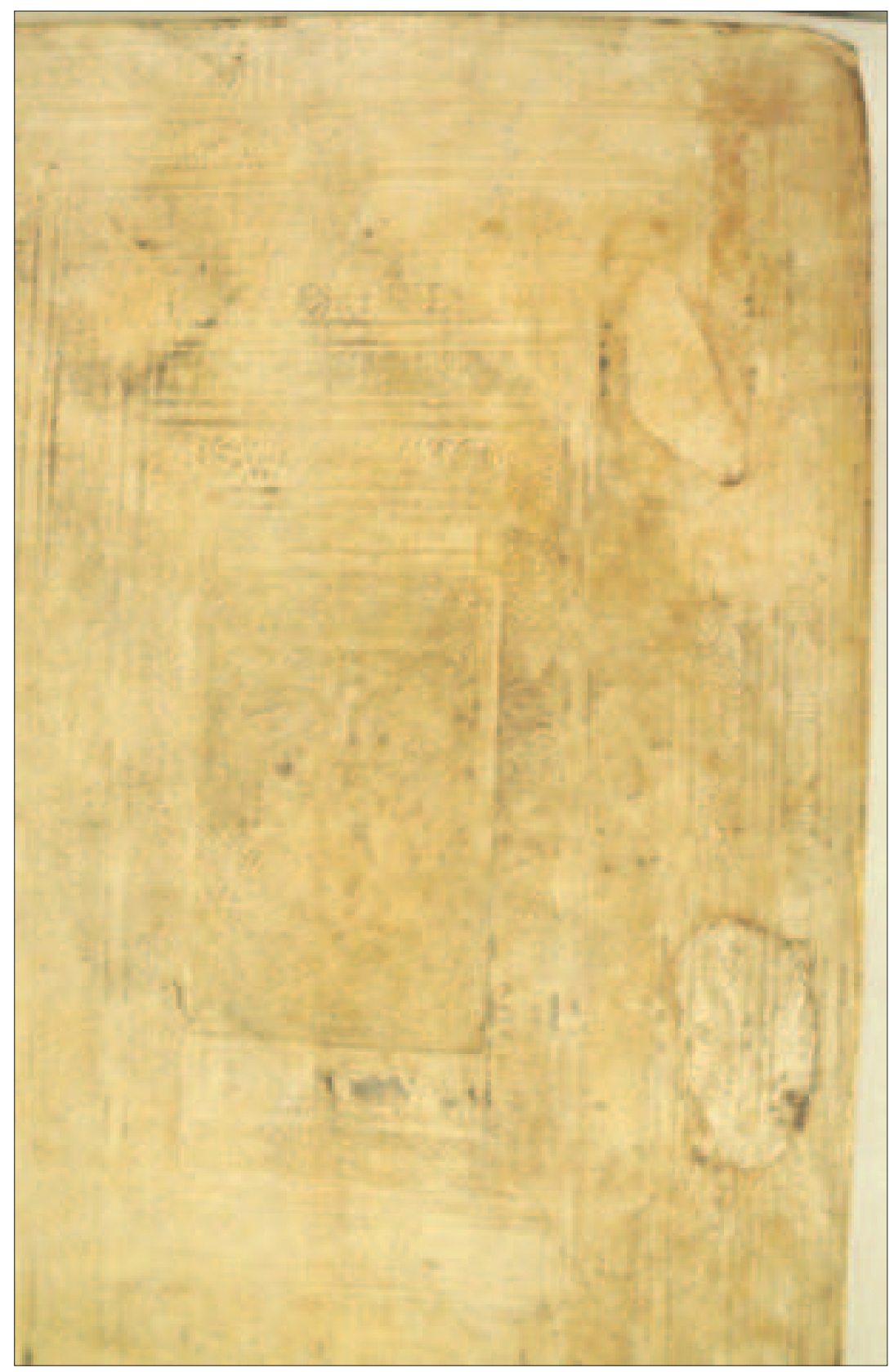

Fot. 1. Skóra garbowana glinowo użyta do oprawy księgi, starodruk, okładzina przednia, zbiory Biblioteki Elbląskiej (fot. T. Kozielec) 
[274]

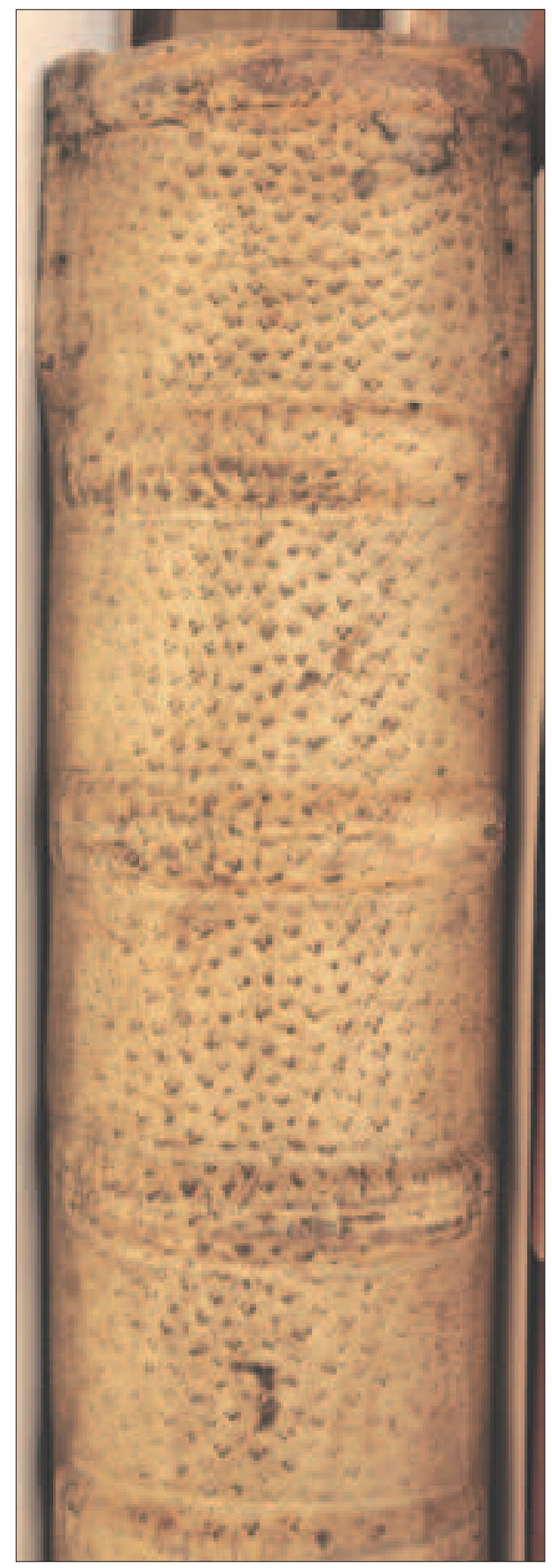

Fot. 2. Skóra garbowana glinowo użyta do oprawy księgi, starodruk, strona grzbietowa, zbiory Biblioteki Elbląskiej (fot. T. Kozielec) 


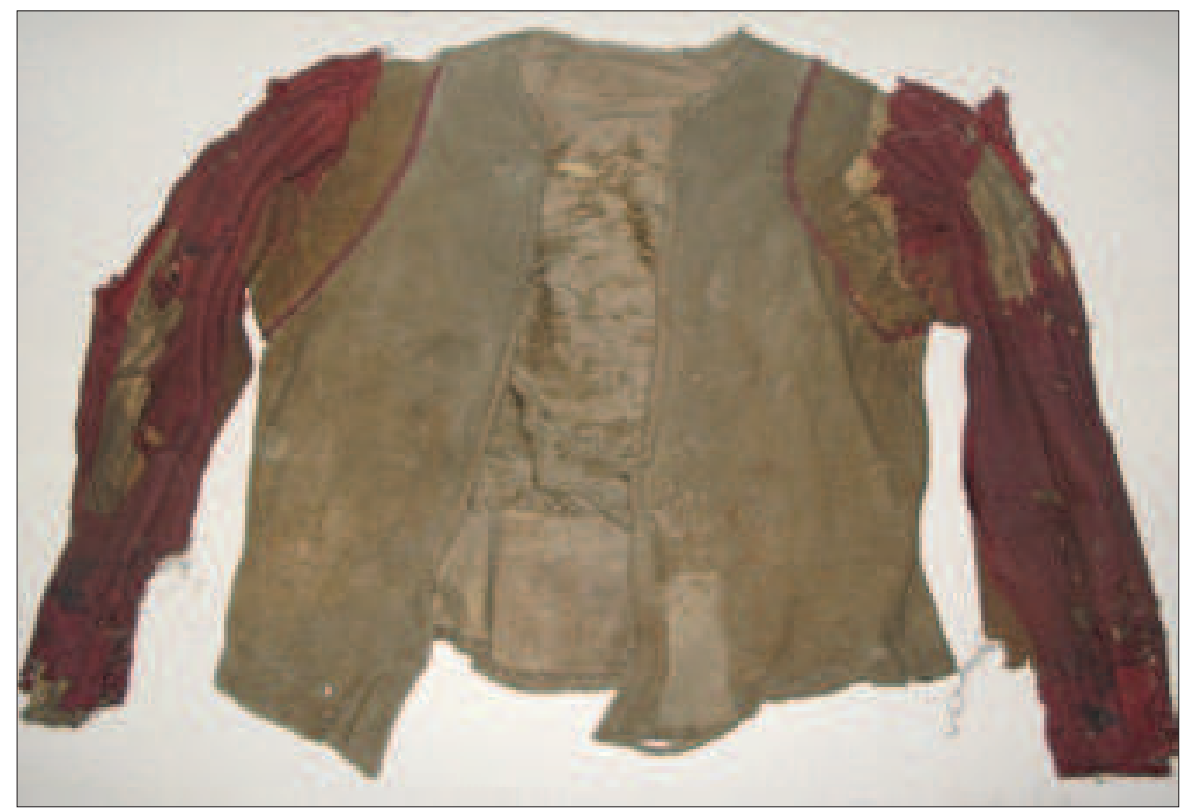

Fot. 3. Kaftan pod kolczugę wykonany z tkaniny i skóry garbowanej glinowo (mocno zabrudzona), stroną mizdrową na zewnątrz, ok. 1700 r., zbiory Biblioteki PAN w Kórniku (fot. T. Kozielec)

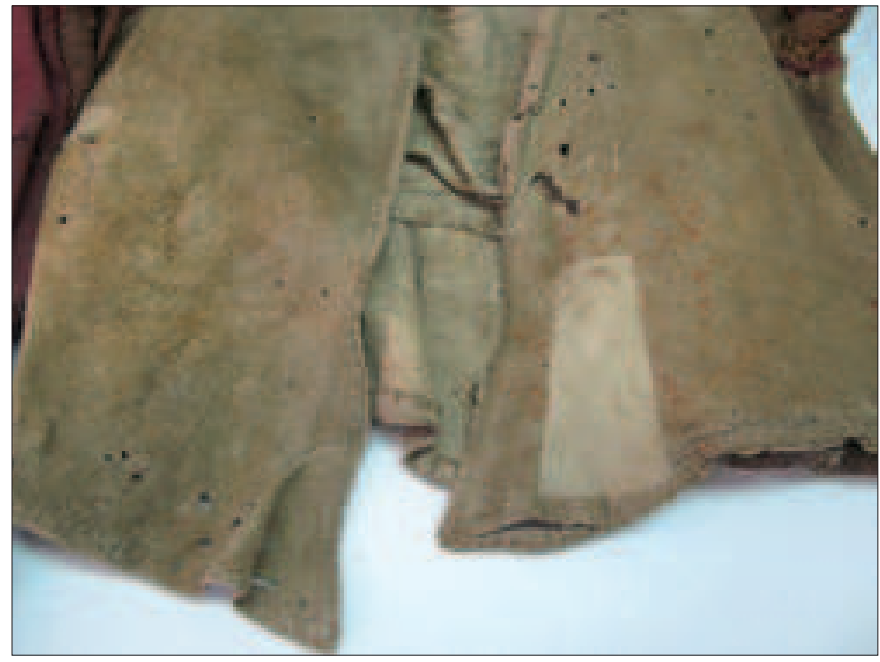

Fot. 4. Kaftan pod kolczugę wykonany z tkaniny i skóry garbowanej glinowo - zbliżenie części skórzanej, ok. 1700 r., zbiory Biblioteki PAN w Kórniku (fot. T. Kozielec) 


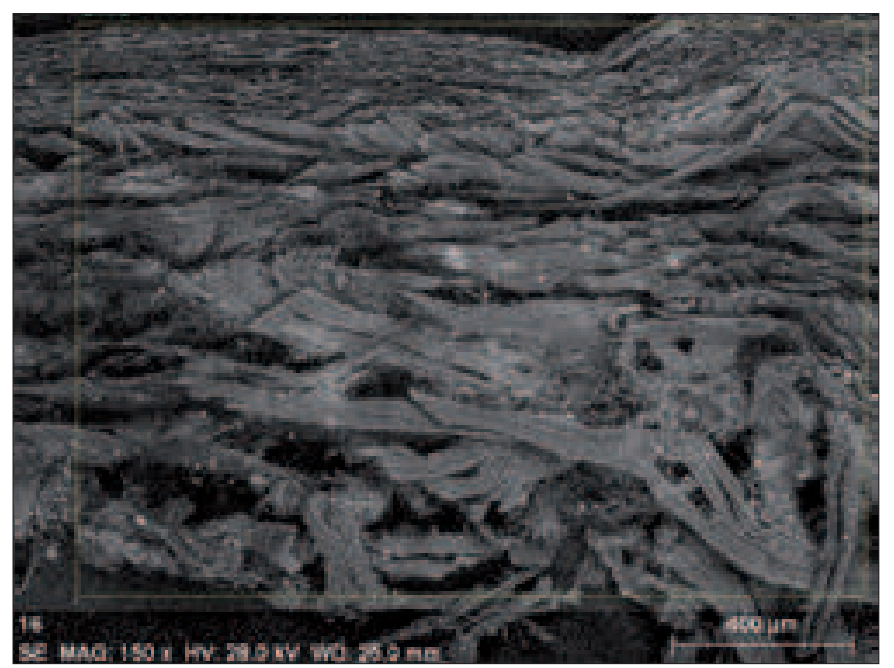

Fot. 5. Próbka białej skóry garbowanej glinowo pochodzącej z paska spodni (pod kolczugę, ok. 1700 r.). Obraz przekroju próbki uzyskany przy użyciu detektora BSE. Żółtą ramką zaznaczono obszar pomiaru próbki do wykonania analizy EDX. Zawartość glinu w badaniu EDX (patrz opis fot. 6) wyniosła 2,45\% atomowego dla badanego obszaru, powiększenie 150 x (fot. G. Trykowski, T. Kozielec)

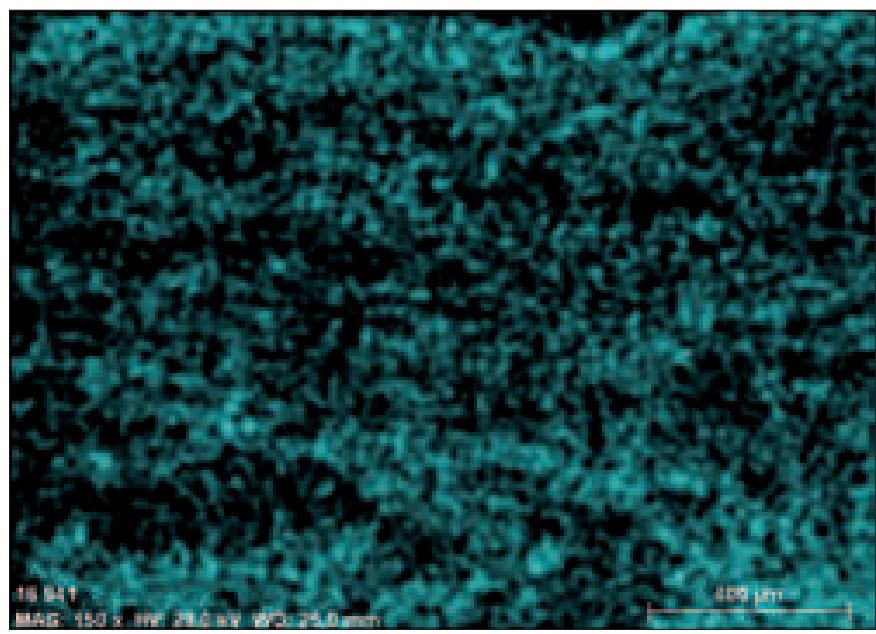

Fot. 6. Próbka białej skóry garbowanej glinowo pochodzącej z paska spodni (pod kolczugę, ok. 1700 r.). Obraz przekroju próbki uzyskany przy użyciu detektora EDX - mapa rozmieszczenia glinu w całej próbce świadcząca o występowaniu glinu na całej grubości próbki skóry, co jest specyficzne dla tych skór, powiększenie 150 x (fot. G. Trykowski, T. Kozielec) 

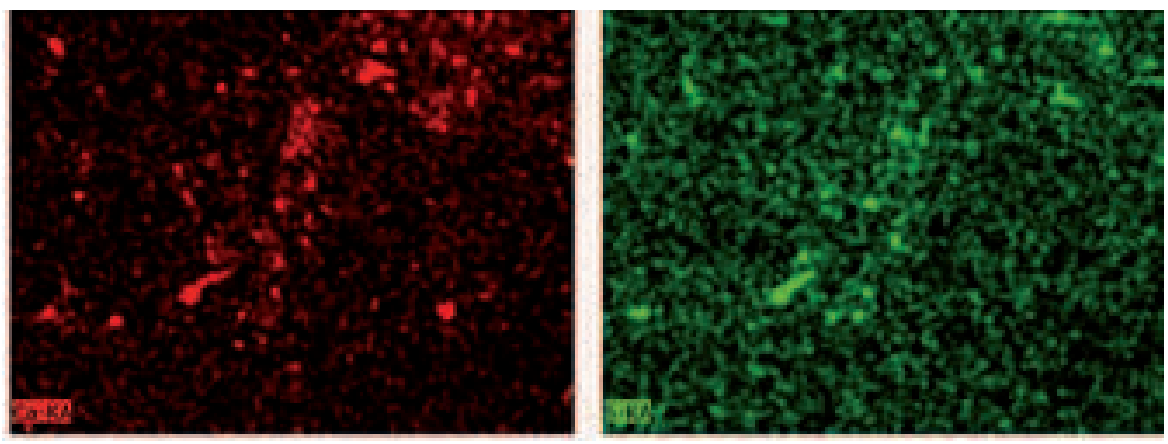

Fot. 7 a i b. Próbka źólto-kremowej skóry garbowanej glinowo, pochodzącej z lamówki zabytkowego siodła. Obraz powierzchni próbki uzyskany przy użyciu detektora EDX - mapa rozmieszczenia wapnia (kolor czerwony) i siarki (kolor zielony) w całej próbce świadcząca o obecności gipsu, powiększenie 1000 x (fot. G. Trykowski, T. Kozielec)

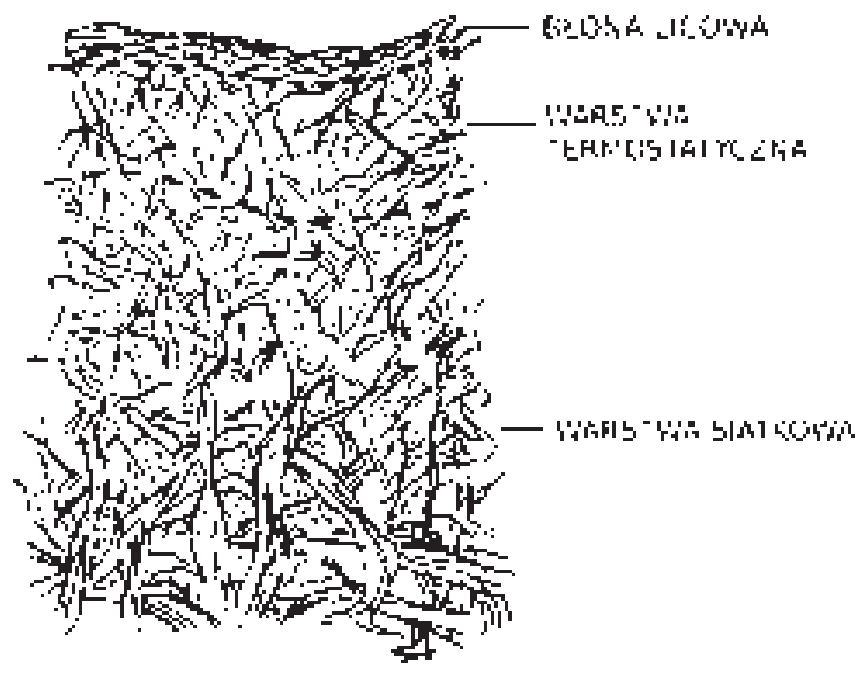

Rys. 1. Schemat budowy skóry wyprawionej (3 warstwy oddzielono od siebie linia przerywana) (rys. T. Kozielec) 


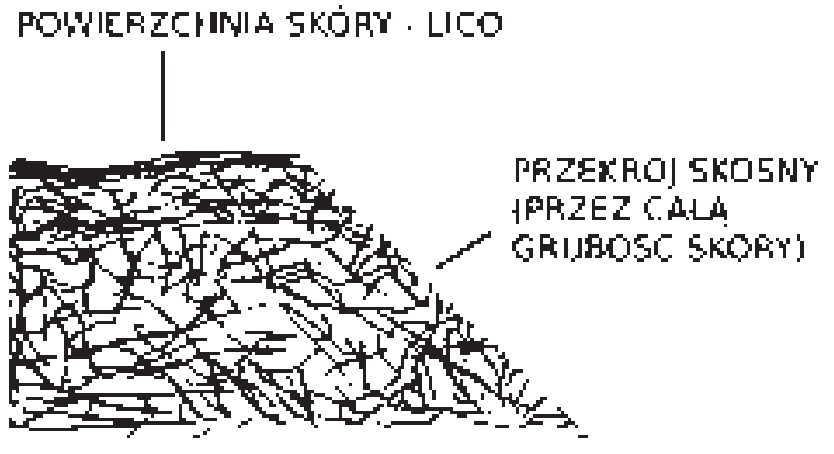

Rys. 2. Przygotowanie próbki do badań powierzchni wraz z przekrojem skośnym (rys. T. Kozielec)

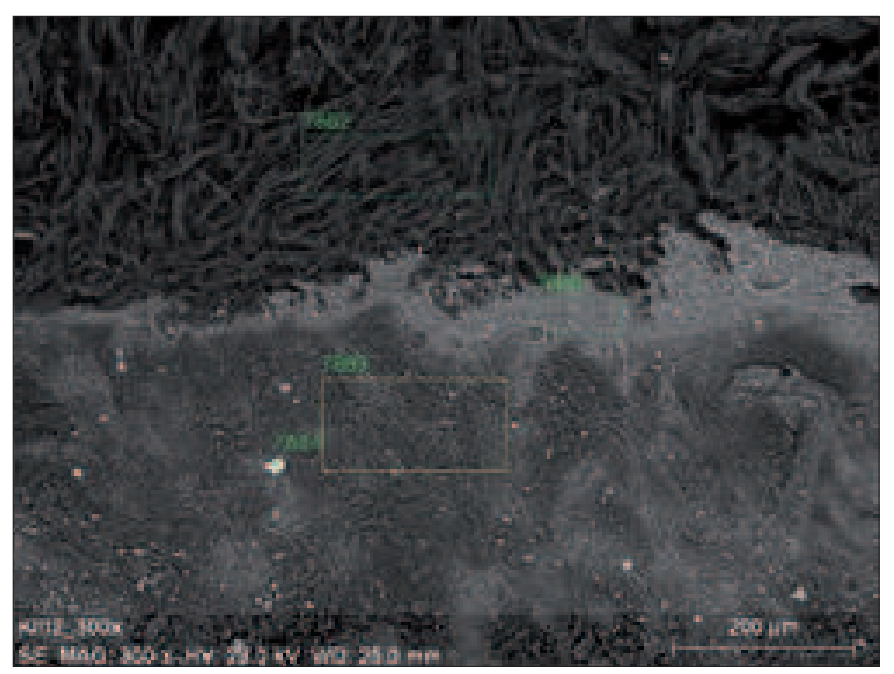

Fot. 8. Próbka skóry garbowanej chromowo pochodzącej z łatki (po XX-wiecznych reperacjach) użytej do wtórnej oprawy „Złotego Kodeksu" (Archiwum Archidiecezjalne w Gnieźnie). Obraz powierzchni próbki (partia od połowy w dół - jaśniejsza) i przekroju skośnego (partia od połowy w górę - ciemniejsza) uzyskany przy użyciu detektora BSE. Zaznaczono 4 miejsca pomiaru: 3 obszary prostokątne $(7882,7883,7886)$ i jeden obszar punktowy (7884) do wykonania badania EDX, powiększenie 300 x (fot. G. Szczepańska, T. Kozielec) 


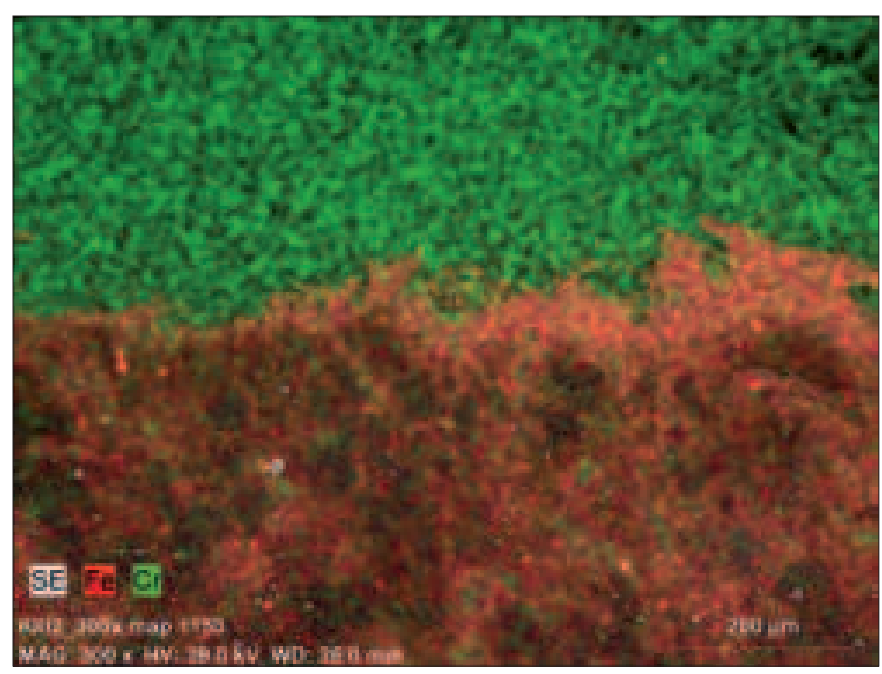

Fot. 9. Próbka skóry garbowanej chromowo pochodzącej z łatki (po XX-wiecznych reperacjach) użytej do wtórnej oprawy „Złotego Kodeksu" (Archiwum Archidiecezjalne w Gnieźnie). Obraz powierzchni próbki i przekroju skośnego uzyskany przy użyciu detektora EDX - mapa rozmieszczenia żelaza na powierzchni skóry (pochodzącego z czerwieni żelazowej) oraz chromu na przekroju skośnym

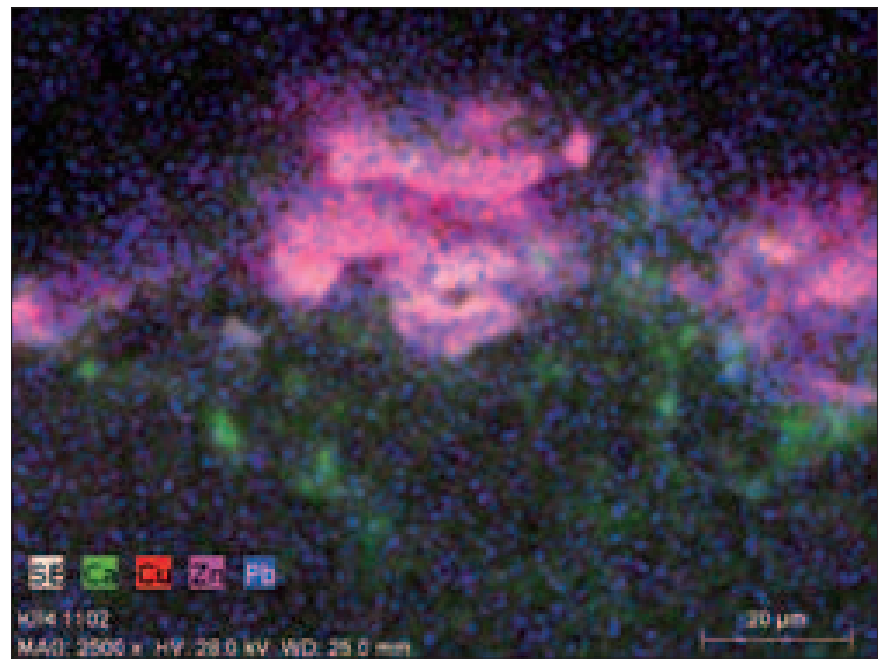

Fot. 10. Próbka pochodząca z pergaminu użytego w „Złotym Kodeksie" (Archiwum Archidiecezjalne w Gnieźnie). Obraz przekroju próbki pergaminu (z imitacją złocenia na jego powierzchni) uzyskany przy użyciu detektora EDX - mapa rozmieszczenia m.in. miedzi i cynku (stop tworzący mosiądz), powiększenie 2500 x (fot. G. Szczepańska, T. Kozielec) 


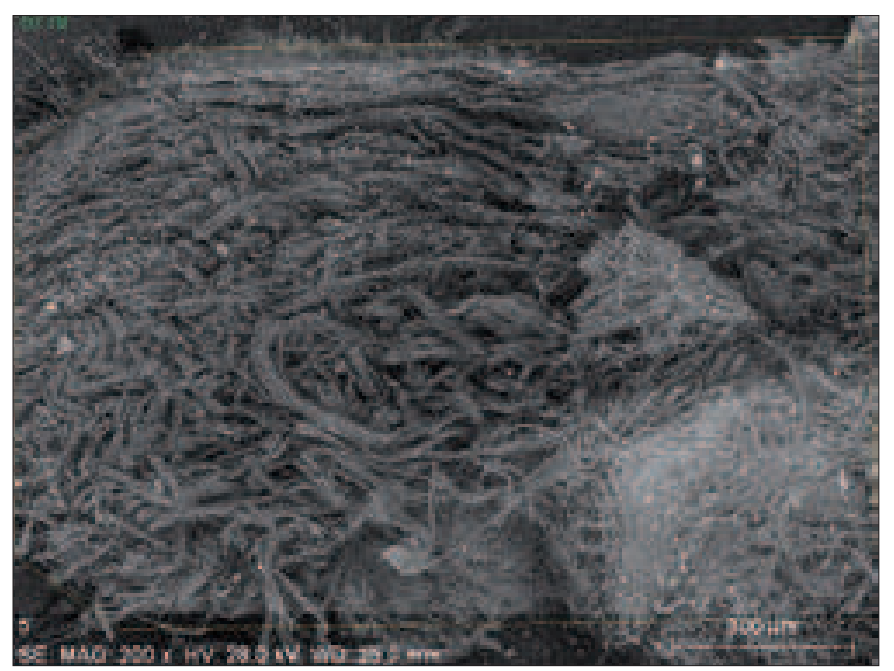

Fot. 11. Zaznaczenie obszaru przeznaczonego do analizy EDX za pomoca linii dopasowanej do kształtu próbki. Obraz przekroju próbki uzyskany przy użyciu detektora BSE, powiększenie $250 \mathrm{x}$ (fot. G. Trykowski, T. Kozielec)

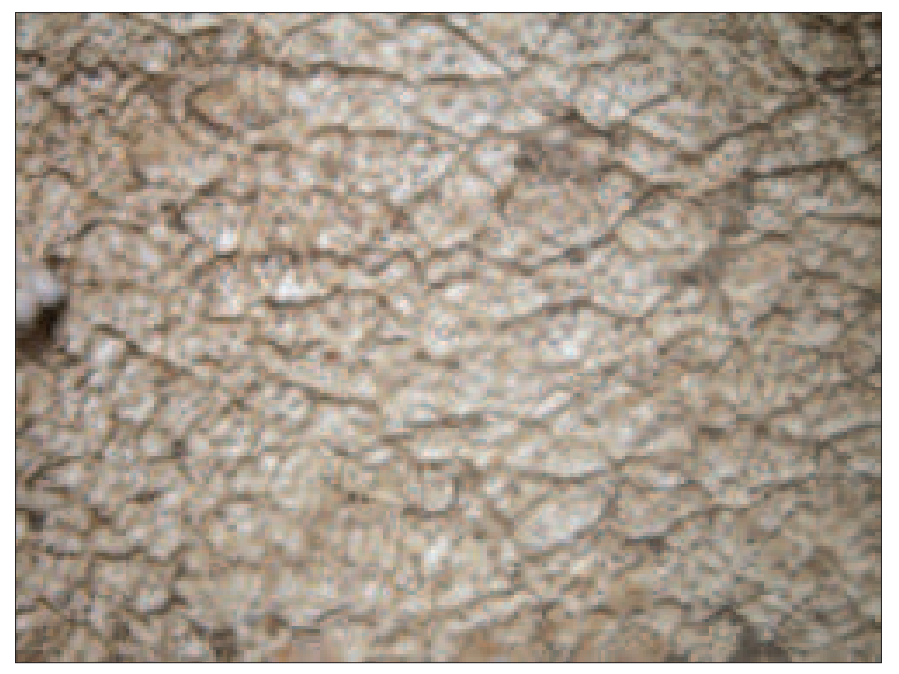

Fot. 12. Skóra z dzikiego zwierzęcia (prawdopodobnie sarna lub jeleń) garbowana glinowo, widok w mikroskopie stereoskopowym, światło odbite, powiększenie 7 x (fot. T. Kozielec) 
[281]

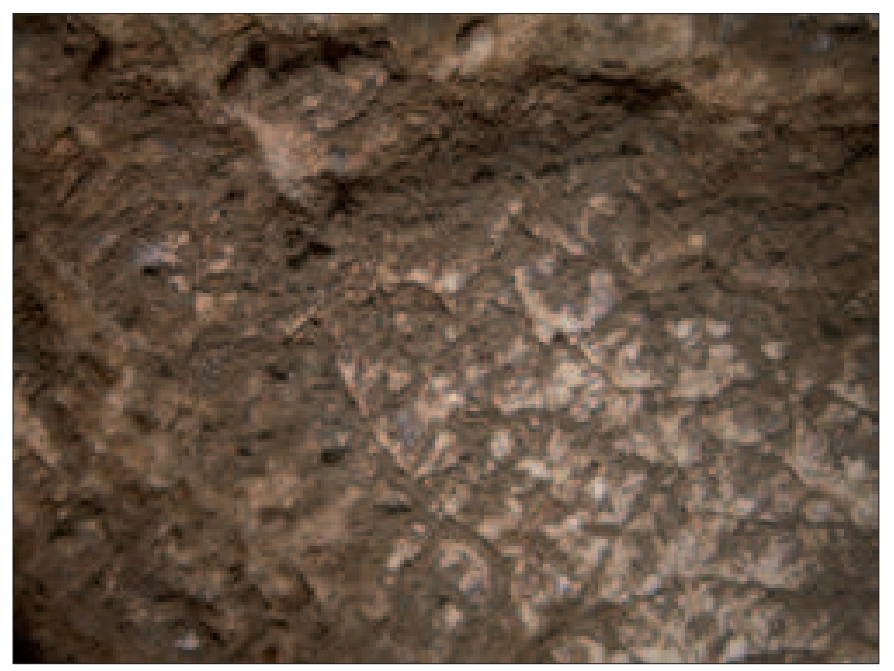

Fot. 13. Skóra z dzikiego zwierzęcia (prawdopodobnie sarna lub jeleń) garbowana glinowo, bardzo intensywnie zabrudzona powierzchniowo, co zwiększyło zawartość glinu w próbce, widok w mikroskopie stereoskopowym, światło odbite, powiększenie 7 x (fot. T. Kozielec) 